\title{
The Dead with No Wake, Grieving with No Closure: Illness and Death in the Days of Coronavirus in Spain
}

\section{Óscar Fernández ${ }^{1}$ (1) $\cdot$ Miguel González-González ${ }^{1}$ (])}

Published online: 20 August 2020

○) Springer Science+Business Media, LLC, part of Springer Nature 2020

\begin{abstract}
The pandemic caused by the spread of Covid-19 is giving rise to an exceptional social situation because of the great speed of propagation of the illness and the high level of mortality it has occasioned in a very short time. Moreover, the lockdown measures decreed in Spain prohibit the holding of wakes to avoid contagion, and limit funerals to three people plus the officiant. Thus, coronavirus is robbing people of the opportunity of a final farewell, stripping the dead of their dignity and worsening the grief of the living. This article investigates the situation and the social and cultural impact it has provoked. The method used takes the line of critical dialogue analysis (CDA) applied to information contained in the mass media, employing qualitative material from a related small-scale study. The results show that in countries like Spain where there is a strong Roman Catholic tradition the importance of these rituals is unquestionable. Although the country has become laicized over recent years, many traditions around death are still maintained. Hence, the impossibility of holding funerals is triggering a large number of social and personal conflicts. Furthermore, they indicate that lockdown, and the lack of rituals and of accompaniment constitute some of the most crucial stressors in the epidemic. Grief in solitude has become widespread and all the more fundamental in a society that values social support from close friends and family members. The conclusions show that the social distancing imposed by the epidemic is especially hard to bear when relatives are passing into death.
\end{abstract}

Keywords Bereavement $\cdot$ Grieving $\cdot$ Mourning $\cdot$ Grief $\cdot$ Covid-19 $\cdot$ Death $\cdot$ Spain

Óscar Fernández

oscar.fernandez@unileon.es

1 Social Anthropology, Department of History, Faculty of Philosophy and Letters, University of Leon, 24071 León, Spain 


\section{Introduction}

The Covid-19 pandemic is having a major negative impact on perceptions of safety and lifestyle. Forced confinement together with bad news about the out-ofcontrol growth in the number of new cases and of deaths, whether locally, nationally or worldwide, have led to an environment of great uncertainty and anxiety. A tottering hospital system, with accident and emergency departments overwhelmed, and the dramatic situation faced by health workers as they attend to patients, merges with the tragedy of the family members of the dead. This arises because when loved ones pass away the possibility of bidding them a last farewell means a very great deal, but it is denied them in these exceptional circumstances. Coronavirus is robbing people of the opportunity for a final goodbye. It is depriving the deceased of their dignity and heightening the grief of those who live on, since they cannot give the dear departed, the relative they have lost, the send-off that would have prevailed if the health situation had been normal.

When a person suffers a loss, whether through death or some other cause, this induces a process of grieving (Niemeyer 2002). The loss arises after some triggering experience that produces a situation of separation. The most frequent losses are relational, in other words those linked with others, people around one who are pillars in one's life. A loss arising from the death of a close family member is the kind with the greatest psychological impact. Furthermore, Galindo (2004) presented grieving as a moral suffering inflicted by the lacerating internal dispossession entailed by a significant loss of what fed the self-esteem of the person affected, and it brings a downgrading of that person's human dignity. For his part, Worden (1997) states that grieving is a natural response to a loss that represents an alteration in the state of health. Just as it is necessary to undertake a physiological cure to restore a body to homeostatic balance, there is a need for a period of time so that a person in the process of grieving can return to a state of equilibrium. Hence, there is an adaptational dimension, and it should lead to acceptance of the loss or a change in the relationship.

Contemporary landmark studies of grieving recognize it as a process intrinsic to each individual (Niemeyer 2002; Poch and Herrero 2003; Worden 2009; Attig 2002). These models concentrate more on the differentiating characteristics of each person such as individual nature, the circumstances of death or the personal confronting of it. Grieving and its relation to sociocultural, historical, family and personality variables has been investigated by Parkes (1972), Rosemblatt (1999), Stroebe et al. (1999), and Weiss (1999), among others. The spiritual dimension of human beings, although not present in many studies, is included by Dossey (1993), who notes the curative power of prayer in grieving, both in the sick who know that somebody is praying for them and even in those who are unaware of it.

For their part, other authors (Bowlby 1980; Kübler-Ross 2014; Lindemann 1944; Klein 1940; Freud 1914) conceive of grieving as a process necessarily passing through stages inherent in human beings and thus universal. Thus, Kübler-Ross (2014), on the basis of her research with the terminally ill in their relationship with approaching death, described grieving as a passage through five 
stages: denial, anger, bargaining, depression and acceptance. Davidson (1979), in a study of adults who had lost a child, developed a concept of four dimensions in the process: shock and numbness; yearning and searching; disorientation; and re-organization. Rando (1984) states that there are three dynamic phases, with varying fluctuations and characteristics, since responses are always personal: avoidance, including shock among other reactions; confrontation, which can include taking the loss on board; and re-establishment, meaning adaptation. Other scholars considering the topic of grieving, such as Weiss (1999) and Sanders (1999), have spoken of various phases, rather than stages, in the process of grieving. Whichever theoretical viewpoint is adopted, all the stages are linked, but not every grieving person has to pass through all of them in the same way, nor to follow a fixed sequence. The main point is to remember that any loss generates a process of grieving in the person suffering it. Likewise, in order for this process to happen in a healthy manner, with no negative repercussions in the future, it must be built up over the different stages, in a variable amount of time, dependent both upon the emotional life of the one concerned and upon appropriate, effective support from those around. It may in some cases require as much as three or four years to reach resolution.

On these lines, Kübler-Ross (1994) pointed out that it is not solely a question of an acquaintance with the stages of grieving, but also of the life lived. It is necessary to add that the attitude towards death in Western societies is one of uneasiness and denial of the fact of death. Faced with mortality, post-industrial society has undergone a disadvantageous evolution. In its material progress, it has regressed from healthy attitudes of facing up to and accepting one's demise, to precursors of phobias in the shape of constant fear of death and to actual phobias of denying its existence. In Western Judaeo-Christian societies, especially those similar to what is to be analysed here, with a solid Roman Catholic tradition, the topic of death has moved further and further away from something natural in life, and people no longer die at home as in the past, but in hospitals. Hence, it is of importance to highlight cultural differences when it comes to handling death and grieving.

One interesting fundamental aspect of this study has to do with cases of people going through grieving for the loss of a loved one. In such instances, as noted in research by Parkes (1972, 2000), Weiss (1999), Weiss and Wodak (2002), Sanders (1999), Worden (1997, 2009), Stylianos and Vachon (1999), it can be shown that any social support provided is a help in preventing the grieving from becoming chronic or pathological. A deficit in social support for those in a mourning process may cause this progression to be more drawn out or their health to be impaired. Social support unquestionably has multiple functions.

Although death comes to everyone, it continues to be a theme that is paradoxically hidden away in a corner. In the context of the new pandemic of coronavirus that has been affecting all parts of the world since the end of 2019 or the start of 2020, daily news programmes represent death in a stark fashion that has virtually desensitized people. This sometimes relates to the losses of life in different countries, with statistics running into the thousands, but above all to how this devilish arithmetic affects individuals. In this situation, decrees instituting states of national emergency or civil contingency in many countries have obliged people to observe 
lockdown in their homes, entailing the prohibition of traditional funeral services so as to avoid propagating the virus. This has turned the situation into something unheard of both in Spain and in other Southern European countries where this study would find echoes, such as Italy, also a land with a strong Roman Catholic tradition.

In this context the objectives of this research are to consider death and grieving during a health crisis in which the established patterns for coping with the thousands of deaths arising from the Covid-19 pandemic have broken down, and to explore the new social situation emerging from the pandemic and the cultural changes that may occur as a consequence of this external factor. The intention is to contribute to the debate on how to analyse the Covid-19 pandemic from the viewpoint of social sciences, concentrating on an enquiry into grieving and death in extreme situations in a post-capitalist, neoliberal age, specifically in a cultural context marked by a Roman Catholic tradition.

\section{Methods}

This study was carried out using what is termed Critical Discourse Analysis (CDA), applied to information carried by the mass media. Such a method allows the relationship between discourse and society to be observed van Dijk $(1999,2000)$, a relationship that is needed, since the media are a means of training and educating. As noted by Meyer (2003), CDA as a research approach should not be understood as a single method, but rather as a viewpoint from which various planes simultaneously acquire consistency. In this way, discourse is seen on the one hand as a product able to reveal certain underlying content, worldviews, opinions, or ideologies. On the other, it is conceived of as an instrument capable of projecting such content into people's social or individual representations. A particularly striking example of this intention to unify the social and the communicative through an analysis of the linguistic is to be found in the discourse strategies envisaged by the historical discourse approach of Wodak (2003) and of Weiss and Wodak (2002). This includes a reference or naming strategy in which, among the arrangements of interest, there is the categorization of belonging. In the present instance this may be assimilated to strategies of intensification and mitigation, identity criteria, metonymy, synecdoche or part for whole, and the like. Moreover, one of the basic characteristics of CDA is a need to bring together knowledge drawn from other disciplines so as to offer a full and appropriate view of its object of study, this equating to a principle of interdisciplinarity. In the present instance, it implies the incorporation of concepts from the disciplines of the authors of this work, Psychology and Sociocultural Anthropology.

The procedure adopted comprised three phases. In the first, there was a trawl of information in the press emerging from experiences, and a descriptive analysis of news about the evolution of the illness, but more especially what had been gone through by people affected by the death of relatives and mourning for them, healthcare professionals, employees of undertakers or crematorium workers. The intention was to make clear the aims of the research, as well as observing the effects of changes in regulations covering the lockdown of people at home, procedures for carrying out interments, and a range of other matters. This was a further reason for 
using the press, written or digital, and daily papers, these having an audience that includes all age-groups and goes deeper into the news, despite the forcefulness of other media. As Moragas (1995) explains, limitations on reading, or replacing it with pictures or interactive texts, which of necessity must be short and summary, may lead to an impoverishment of debate and reflexions upon social realities. At this level of media analysis, the enunciative, the thematic and the rhetorical were sought. The sample considered was made up of information contained in the press, in accordance with the plan given above. Nevertheless, on grounds of sheer volume it was limited to the local and society news sections of the national newspapers that have the greatest circulation according to the Spanish OJD or Oficina de Justificación de la Difusión [this has a role comparable to the British Audit Bureau of Circulation or the American Audit Bureau of Circulations or Circulation Verification Council]. The papers included El País, El Mundo, La Vanguardia and ABC, to which was added material from local news sources, such as Leonoticias or NIUS. The period selected was of particular interest because it coincided with some of the most intense and critical moments of the health emergency in Spain, running as it did over the first quarter of 2020, but primarily from 15 March to 15 April, when the situation was most dramatic. Approximately two hundred news items were considered.

The second phase involved desk-top analysis of the information gathered and permitted the drawing up of categories highlighting the recurrence of themes in the indication of values relating to the situation of those affected. Social and work responsibilities, age and sex were taken into account in organizing the data, so as to guarantee representativeness and diversity, together with socio-demographic factors that might impact on people's motivations, predispositions, linguistic or other habitus patterns, agency and adjustment (Bourdieu and Thompson 1991). In processing the qualitative data Riessman's thematic narrative analysis (2008) was used, in order to establish these categories with greater ease. Codification was carried out inductively by means of constant comparison (Merriam 1998). This was guided by assessments of social and cultural experience, stressing the interest of gaining an acquaintance with people's behaviours and experiences, their capacity to change perspectives and confront critical situations, whether their own or of others, their ability to express their emotions verbally and communicate them, as also a general awareness of adjustments and stamina. In the third phase the information was analysed by setting it within the theoretical reference framework, leading to the discussion and interpretation described below, and ending with conclusions.

\section{Results: Death in a Time of Pandemic}

The idea of death evolves, changes and adapts to each stage of development of a life and throughout history. Ariès (1982) provided a review of how the West has handled the idea of death over the course of time. In the Middle Ages death was something as natural as life, because it was present on a day-to-day basis in homes; a death outweighed by other needs. From the Renaissance until the nineteenth century, deaths give rise to ostentatious and prolonged mourning, with symbols of this worn for 
decades, as in Romantic death. With the arrival of the Industrial Revolution, death became a private matter and hence a bleak, dispiriting, isolated affair. Finally, at the present day, death has turned into a taboo, being seen as an exclusively medical matter, with attempts to make it invisible.

Even at a psychological level, it is possible to establish differences according to what an individual's perception of death may be, that is, whether or not a person is aware of dying. In the Covid-19 pandemic thousands have been dying each day. However, those who have spent weeks in an Intensive Care Unit on the verge of dying, but in the end have managed to recover and leave hospital, in other words have come back to tell of their near-death experiences, describe extremely intense emotional episodes with transcendental aspects. This is what happened to Benjamín Fernández, the first case in Leon, a lorry-driver who returned from a run carrying goods to Milan. After a number of days in the I.C.U., he depicted his experience as akin to coming back to life, that is, like others, he was fully convinced he was at death's door (Moody 1975). The accounts of such people who have recovered after days in intensive care are generally alike, and they all have a number of similar elements: cognitive, going back over their life; affective and transcendental, remembering family members, including those who have already passed away; and psychosocial or of changing lifestyle and priorities, and greater spirituality. As Greyson (1985) states, all of this is doubtless an outcome of stress or a consequence of anoxia or hypoxia. According to Sanz (1995), in such near-death experiences most people realize they are dying. However, it is possible to hold, as Nomen Martín (2007) suggests, that to alleviate this feeling the body is sufficiently intelligent to achieve a painless death, even by means of endogenous analgesic mechanisms. A further aid is that spiritual sentiments are reinforced in these critical situations. Independently of any beliefs about life after death, it appears important to believe in something, since this makes the coming challenge easier both for the moribund individuals and for their relatives.

Apart from this more encouraging feature of recovered patients, the situation arising from the health crisis of coronavirus discussed here is one in which many victims of Covid-19 are dying in isolation in hospital, bereft of the company of family and friends. Visits are forbidden because of the extreme risk of contagion. Accident and emergency departments are in a state of collapse. The dramatic circumstances facing healthcare workers, and not just in Spain or Italy, are terrifying and unbearable. The great majority of victims have died alone, perhaps without really understanding why they have been abandoned during the most feared episode in their lives. This was pointed out by Antonio Cano, a doctor in an overwhelmed hospital in Madrid:

That's the cruellest thing about this pandemic. The thousands who have died from COVID-19, passing away alone. In a hospital ward or a room in an old people's home. Without family members near them. Not one goodbye or farewell.

Without a doubt the consequences for survivors may be bleak, because they will form a part of the pathology of grieving that has not reached closure or been overcome, in other words, the pangs of guilt for not having gone through normal 
sorrow and mourning. From a psychological perspective, it might be expected that there could be anticipatory grieving, the sort which occurs when patients are so gravely ill that their death can be foreseen, whether this is in cases with prior serious respiratory illness, in the elderly, or in individuals with other potentially complicating pre-existing clinical conditions.

Anticipating the loss of a loved one can be as painful as a real loss, but at least it allows a family to prepare for the inevitable farewell. They can seek support from key people, whether these are spiritual leaders, family members or friends, or they can clarify the wishes of the person involved in respect of end-of-life matters.

This was stated by Gloria Oña, who lost her mother, a resident in an old people's home. She constantly laments not having been able to be at her side:

When coronavirus comes calling in the shape of a positive test, they have to isolate the sick people and anybody who's come into contact with them. Then it's prepared for the worst, them and their families. If it happens, they'll die far from their folks. The sick who die are cremated unaccompanied. Their families are shut away in their turn, nearby, but as far away as the edge of the universe. Despite having been weeks without seeing them, touching them, speaking to them, cuddling them, they remain emptyhanded.

On the contrary, with so many dying, what is happening is that there are cases of sudden loss, where the grieving process becomes much more complex, since an unexpected death causes such processes to be difficult and may trigger other psychological problems. It is saddening to learn that loved ones or friends have died in hospital without it being possible to be with them in their last few days. It is easy to imagine that they may have felt abandoned, and that is a very painful feeling. To this must be added the fact that in most instances things came to a head so rapidly that it was practically impossible to foresee anything. These were the ideas of Sonia, who lost her eighty-four-year-old father:

Just over a week after they detected coronavirus, my father started getting worse. He couldn't catch his breath and an ambulance took him off to the hospital in Santiago. I know that when he left he told us he wouldn't be back. He already had it in his head that he wouldn't be coming back. Two days after he was admitted, a doctor rang to say there was nothing more they could do. It was all so quick. He died in the morning, and by four in the afternoon they were burying him.

Moreover, after death, the corpse is generally taken directly to the crematorium or the tomb. There can be no embalming and no choosing of the clothing envisaged, no viewing of the body, no holding of the funeral as would have been desired, so there remains a sensation of not paying respects as one would have wished, and as the loved one deserved. Apart from these problems, people miss what might be considered the most important thing at such a difficult time, the opportunity of receiving comfort and compassion from family members 
and friends. It may perhaps be some consolation that, even if the victim has died alone and far from the family, the healthcare workers were there with the person. However, these professionals are human, too, and can break down, like Lucía Galán, a doctor, who noted:

I see patients dying alone, without their family, their people, without a hand holding theirs, without a farewell, without anything and it breaks my heart.

Nobody's invincible, not even doctors. Nobody's ready to die alone.

Likewise, as will be seen below, there are situations in which grieving must be deferred. The family and friends have to take their leave hastily, and direct their immediate attention to other urgent matters thrust on them by the circumstances.

\section{Grieving in a Time of Pandemic}

The Covid-19 pandemic has led to delayed grieving processes. Relatives and friends are obliged to bid farewell in a hurry and take immediate care of other urgent calls imposed by the situation. However, until this grieving can reach closure, this state of affairs has short- and medium-term consequences.

The moment of saying goodbye to a departed family member is a crucial part of the process of mourning. It fulfils a communal function in which participants show support and solidarity in the face of circumstances that come to all with time. In the current pandemic, this is strongly discouraged; indeed, all gatherings are prohibited, so as to avoid spreading the coronavirus. This inability to perform a funeral ritual may make the grieving process more complex, constituting an added factor of stress, anger and anguish for family members. This is because they cannot carry out the wishes of the deceased or have relatives and friends present, and sets a limit on the emotional support available.

This reality brings a new type of sadness, both individual and communal. The community itself must struggle with the significance of death through a pandemic and with the conclusions, true or false, that emerge from it. Such deaths confront a community with its fears and uncertainties, with the idea of the end, and with overall thinking about the future. Moreover, the feelings of guilt and anger that often accompany losses may be exacerbated, for example, in contexts where there are suspicions about who infected the deceased. The prohibition on having an open coffin, together with other restrictions, may lead to pathological grief. The tendency to feel isolated that normally comes with states of grieving may be confused with the isolation imposed by regulations, which can aggravate sensations of grief and loneliness.

\section{Mourning in Lockdown: The Absence of Wakes}

Thomas (1993) states that attendance at cemeteries, as places of peace for the soul, involves them as symbols charged with emotions, triggering not just sadness and melancholy, but also calm reflexion. They are a complex spiritual symbol that attempts to express what humans have experienced at a number of levels. This 
symbol awakens deep emotions, revealing to people how precarious their situation is on the shaky bridge of time, and that is daunting.

In countries with a strong Christian heritage like Spain, tradition calls for people to gather around the deceased, remembering them and accompanying the family, but this has not been possible in these days of pandemic. Funeral wakes formed a part of Spanish traditions until very recently, when they were gradually replaced by the somewhat similar action of viewing, now held in the funeral parlour. Wakes were a way of mitigating the grief of family members and a route to doing justice to the departed, recalling their lives, their doings, and their tales. The whole essence of what was this form of valediction and solidarity with the deceased's close circle has been swept away by the coronavirus. Many of the affected are from a rural background in which traditions are more deeply rooted and it is essential to bid a "good and proper" farewell to the deceased.

\section{Losing More than One Beloved}

Circumstances making this pandemic worse, as has happened in others over the course of history, would include the sickness and loss of more than one family member. Things become far more tragic. If the loss of one person dear to you without being able to bid farewell is a tragedy, it is hard to conceive the grief of people who have lost more than one relative, perhaps, indeed, both parents, on the very same day or in a short space of time. With all that is going on, the most impactful item may well be trying to form an idea of how such individuals must feel, while at the same time they are confined in self-isolation. Merely imagining having lost several relatives, while in addition being in lockdown or in quarantine at such a crucial moment, shows how this could bring people to the breaking point of their mental health.

This was the case recounted by Susana, who lost both her brother and her husband to Covid-19. Her brother lived in another city, working as a schoolteacher. He had a meeting at the school with a former fellow-student, who had just returned from Italy and was unaware of having contracted the illness. Her brother and his wife both went into quarantine, while her husband, aged 58, was admitted to hospital in Madrid, and from the second day of his stay onwards she was not allowed to see him, and no visits were permitted.

I was nine days without being able to hug him or to be with him, but the doctors did call each day to give me the news, and they even gave us a chance to talk through a video call. He died alone, in a hospital ward, I didn't get to say goodbye, I couldn't even kiss him when he was taken for cremation because the coffin was sealed.

I wanted to say goodbye to them, but I couldn't. I know I did all I could to get to see him and hug him. It's horrible to be crying without a farewell to my husband or my brother. I'm not to blame for not doing it, but I'll always have that void in me and grief, and my loathing for this thing called Covid-19 which is warping all our lives. I'm going through this all alone. I miss a hug. My only consolation is that a doctor told me that my husband didn't suffer. 
Gloria and Pilar, two sisters, lost their mother and father aged 81 and 93, who were residents in an old people's home in the Basque Country. The last time they gave their mother a hug was before anyone tested positive in the home. Now they regret they could not be at her side. They were not even able to go to the funeral parlour:

Not being able to see her at such a moment gave me a feeling almost as if they had been lepers. I'm really upset because of this situation, because of not being able to do what they deserved, and that's going to stay here inside us ... You can't forget that in their last days you weren't with them. You get the dreadful news, but it seems as if they're talking about somebody else, as if it hadn't happened. The call you, they tell you, and that's it, you're on your own. At the time when she was being cremated, I lit a candle in my house.

Their father died four days later. A history of complicated, earlier losses, personal or shared with family members, cannot but make grieving more difficult (Simons 1979).

Misfortunes are arriving in many ways, but day centres and homes for the elderly symbolize the greatest tragedy in this pandemic: the horrendous data coming from within their walls, with thousands dead in such residential facilities. The residents cannot receive visits for their own protection; at times the only thing available to help bear the distance and the fear is a weekly video call.

Sonia Valiño lost her father in the last week of March, when the coronavirus crisis was at its worst, and she could not even go to the cemetery, because she was infected as well. She had not been able to be with him in his last moments of life, either. She could not have a wake for him nor see him buried. The same virus that had carried him off prevented her from bidding him farewell:

I've spent five weeks shut up in my house for nothing. I asked for the hearse to drive past my home and I said goodbye through the window pane.

\section{Coping Strategies of the Two Sexes}

The story of these women is a reflection of the experiences of many who are unable to bid farewell to their loved ones. However, they manage to live through grieving from a different angle.

With reference to the sexes, the coping strategies used by men and by women are a differential feature, as well. In the information considered, there was a high percentage of accounts by women, three quarters of the total, as against those by men, almost in inverse proportion to the incidence of the illness by sex. Women set store on expressing their feelings and seeking external supports. In contrast, men try to rationalize and look for explanations, although they may also show emotions of anger and guilt that can became disadaptive (Martin and Doka 1996).

The disruption of grieving among women takes striking form in remorse, in that unplumbed limit to any loss, which Loraux (1990) states women represent in paradigmatic fashion. Similarly, Sanders (1999) highlighted the greater capacity for socialization of women when seeking social backing, which facilitates their process 
of grieving, relative to men, who are more dependent upon the emotional support of their wives or of other people in their circle. Lacking this, they have become sunk in some form of social isolation. It has even been noted that men tend towards negative behaviours after a loss that they have not been able to get over (Schuchetr and Zisook 1993), for example adopting some form of addiction, including becoming workaholics. Siegel and Kuykendall (1990) claim that a connection with a church or other religious organization can serve to reduce stress in men.

Consideration will now be given to the importance of funeral undertakers and cemetery staff in the grieving process.

\section{Cemeteries: The Tragedy of Burials Without the Family}

A look at the data made it possible to see that it was as if this pandemic killed two times over, since it first isolates victims from their families just before dying. Then it does not allow anybody to achieve emotional closure. It strips the dead of their dignity and aggravates the grief of the living. The states of emergency decreed in various countries do not permit the holding of the funerals which would normally set a term to grieving.

In such circumstances, staff from undertakers have suddenly found themselves acting as replacements for families, for friends and even for priests. More than this, the close families of the victims dying of the virus are frequently in quarantine. The result is that at least once a day there tends to be a burial without even one single person turning up to bid farewell, either because their relatives have also been admitted to hospital, or because they are all quarantined. Luis Miguel, a grave-digger in the Madrid funeral service described a scene that stabbed him to the heart:

It was the toughest experience I've had since the start of this health crisis. We had to bury a women, but when the hearse arrived we discovered that only the coffin had come. Nobody else was with it. The deceased's husband and son were in hospital. They had coronavirus, too. So it was us grave-diggers who had to give her a last farewell, with the greatest respect.

Such staff have become essential in order for everyone to find some modicum of peace on coming to the cemetery to say goodbye to relatives. They listen to families who arrive in a terrible state, generally wanting to see their loved one for a final time. This was mentioned by Javier Martín, another grave-digger in the Madrid service:

People ask us to open up the coffin so that they can be sure that the body in the casket is really their relative, because in some cases a lot of time has gone by and it's normal for them to have doubts, or sometimes it's to be able to see the body for one last time, or to put some personal object inside the casket, some family heirloom. The rules forbid that, to avoid contagion. ... Besides, the farewell has to be almost in solitude, at most three people. It's a bit sad, because you haven't got the support of your family or friends, it's all very lonely, very sad. Nobody feels able to say a few words, so there's just silence. 
Although health authorities state that the virus cannot be transmitted after death, it can still survive on clothing for a few hours. The dead cannot be buried as tradition and custom require, with their best or favourite clothes. Instead they are left wearing the dreary, impersonal gown of a hospital patient.

Miguel Valero, a grave-digger in the Madrid funeral service stated that there had been occasions when he and his colleagues had buried two people from the same family at one time, because they had died together. Some hearses even arrive without a single relative accompanying them, because all the family members are in hospital or in quarantine. He added:

Although we're used to seeing death close up, we weren't prepared for this. The hardest thing is not being able to relieve the suffering of the mourners. That's really sad. They can't stroke the cheek of their loved one for one last time or grasp their hand, and not seeing them off in a dignified way is a trauma.

Unquestionably, these small gestures are very important for those grieving. As only three family members are allowed to attend, they normally ask for the burial to be recorded so as to pass on the recording to other relatives. It is a highly disturbing scene for anyone who has just seen a loved one die. A coffin arrives in a hearse, and a priest blesses it right there, without the casket being removed from the car, but more than that, there is the loneliness of it all. In seven or eight minutes the burial is over, and then there is another victim waiting.

Each hearse is accompanied by just two or three people, maintaining social distancing. They are separated by red-and-white striped tapes from the columbarium niches where the victims will lie for their eternal rest. All those present remain spatially separated, but united by a tragic sensation of emptiness: their loved ones fell ill, they hoped against hope that they would recover, they were unable to be with them during their last few days, and their departure from this world has come much earlier than foreseen. In these circumstances, families may even still not have fully grasped they have lost their relatives forever, or just how extensive the pandemic is. Their emotional burden is very heavy.

Those who decide to have their family members cremated have to wait many days, pending a call to tell them when the cremation can be. As an example, Eulalia's husband died on 23 March. She was finally told that on 12 April he would be cremated.

An analysis of the information gathered makes it plain that the sensations of grief, emptiness, sadness and anxiety are often compared to wartime. This was the description given by Luis Miguel, who had already gone through very distressing situations in the cemetery where he works:

My feeling is that this is like a war. When I leave home in the morning there's nobody in the street. Here in the cemetery, it's heart-wrenching. My colleagues with the most time in this job say this crisis is the worst they've had to face. Worse than the 11-M terrorist attack [that occurred in Madrid on 11 March 2004], and worse than the Spanair air crash [that happened in August 2008]. 
Doubtless this epidemic is outdoing other critical events in some ways, but it still has points of correspondence with grieving that has not found closure, such as the case of the disappeared, of whom it is known that they must be dead, but about whom there will never be the absolute certainty that permits a closure for grief. These are instances like those cited by Ferrándiz (2014) on referring to burials as being decent or not, speaking of bad, insufficient, offensive or pre-cultural burials, lacking the proper rituals and mourning, undifferentiated and disorganized. An example would be the account given by the mother of Lucio, a victim of the virus, who stated that she had not been able to be in the cemetery as is normal for people, and she had not been allowed to weep for him as he deserved. Similar characteristics are reported in the study by Kelly (2011) on the experiences of firefighters at the scene when the World Trade Center collapsed after the terrorist attack. A well-nigh fanatical insistence on having physical contact with the bodies of people important to one after they die emerged as a crucial element in the grieving process, allowing it to move on to a phase of recovering from a traumatic loss.

\section{Emotions and Social Support After the Death of Somebody Close}

Human beings are social creatures who build up strong emotional links with the people around them from the moment they are born. These affective bonds are very durable and intense, and to a great degree constitute the basis for social groupings like couples and families. These links are not broken off abruptly, but take a long time to diminish. For them to fade, there must be a normal process of grieving. According to Rook (1987) the most important events in the life of an individual require help from others, buttressing or companionship from society, in which social interchanges provide recreation, humour and affection to contribute to a sensation of wellbeing. The ways in which each culture promotes the tasks of grieving, the expressing or suppressing of the feelings of a mourner, and social support, are factors considered vital in respect of their impact on the health or sickness of the members of any given culture. Likewise, they are related to the practices, and religious and spiritual beliefs, of each sociocultural grouping (Parkes 2000). Hence, these underpinnings may offer protection from the effects of stress arising in daily life, as well as providing a sensation of friendship and companionship that wards off the feelings of emptiness and despair associated with loneliness and death. Indeed, as has been observed here, one of the most crucial stressors in this epidemic is that people have to face up to the death from coronavirus of relatives under lockdown conditions for the whole population, depriving them of any possibility of being with them in their final hours, of bidding them farewell or of attending their funerals.

The death of a loved one is known to be one of the most painful experiences for any human. At the present time, as noted above, the pain is doubled because it is no longer possible to say goodbye, voices cannot be heard and contacts cannot be made. Moreover, this must be borne alone under lockdown or in quarantine by people who are twice shut away, first from the world outside, and second from their own inner world where feelings, emotions and thoughts should be located, key elements in giving grief a meaning. As a function of the differences between cultures (Schieffelin 
1985), there are expectations that joy, sadness, anger, fear, surprise, disgust or interest will be expressed to a greater or lesser degree (Ekman 2003). Mourning emotions are considered universal and manifest themselves as rage, powerlessness, guilt, grief and tears, something natural in giving feelings a bodily outlet (Rosemblatt 1999). Sensitivity to cultural differences should prevent any ethnocentric assumptions that one's own culture or experiences necessarily provide a solid basis for understanding the grieving of somebody from a different cultural context. Ana was the daughter of a doctor who caught the disease while undertaking his professional duties and passed away just a few days later, and her tirade against the hospital where he died is significant for the context being studied:

I'll never be able to forgive the inhumanity of not letting your daughters into be at your side in the hospital, holding your hand and hugging you tight. No chance of caressing you, or giving you a last farewell kiss.

Adjustment processes always include a phase of aggression and destruction, since there is a breaking down of old structures so as to adapt to the new. The emotions of rage and anger, so present in grieving, have this adaptive function of destroying the old, even if they are projected onto medical deficiencies or onto institutions, as usually happens in Western societies (Kübler-Ross,1994). Sadness, accompanied by a sensation of emptiness, and the anguish reflected in facial expressions and the tone of voice constitute a call for help launched towards others (Ekman 2003). As stated above, such social support, the aid and affection of relatives and friends, has curative powers. In this way, tears are one of the many resources available for relieving grief, acting as one of the body's natural healing mechanisms. When people are mourning, there are often two attitudes towards weeping. One is the use mentioned above, as a relief for feelings of sadness. The other is a belief that one should not cry so as not to end up disconsolate, leading to attempts to avoid crying. Kessler (2004) states that unwept tears serve to deepen the well of sadness.

\section{Video Calls to Ward off Loneliness}

The coronavirus pandemic, happening as it has in a context dominated by mass communication via networks and the Internet, is markedly different from pandemics that occurred at earlier points in history. Living one's grief in cyberspace seems to permit a return to the shared experiences of pre-industrial times. These gradually disappeared as there were outbreaks of epidemics in the nineteenth century, which required numerous sketchy funerals and finally led to a prohibition on burials in churches, relegating interment to modern cemeteries set well away from communities.

From study of the data gathered, it can be seen that in an era of virtual socialization public manifestations of a grief that was previously private have once again attained a significant weight. In some cases they follow traditional practices, while in others, they replace them. There are many examples illustrating this change in the narratives. Hence, for instance, in obituary notices published in various print media or on the web-pages of funeral undertakers, rather than the address of the mourner, 
a WhatsApp number or an e-mail address are given for senders of messages of condolence. Similarly, various forums and platforms have been established to unite relatives of coronavirus victims, such as https://www.plataformafvc19.com/, set up by a group of psychologists after one of them went through a tragic experience. In addition, the website of the Spanish national broadcaster Radio Televisión Española has opened a Coronavirus Memorial as an antidote to the rushed farewells forced on people by the pandemic (rtve.es/coronavirus/memorial). This is an interactive collaborative project where individuals have a chance to pay homage on-line and bid a final farewell to the victims of the coronavirus. Apart from these on-line memorials, there are virtual graveyards and cemeteries in social networks.

On-line wakes have carved out a place in the "new normality", despite rejection by some funeral directors. Applications offering virtual condolence notices can act as a makeshift during the coronavirus crisis, even if traditional undertakers look on them with mistrust and reject their services. For example, the Alife application is from one of the many enterprises that offer on-line wakes, digital condolence books or streamed funerals. Although these were already in existence, distancing measures ordered under the Spanish State of Alarm have led to a boom in use, up to $400 \%$ in this instance. Regardless of any income it may generate, Alife 's greatest value is that of providing an alternative to solitary sorrow and to ceremonies with masked mourners two metres apart. Another example is Eternify, which operates in Spain with a different philosophy. It does not offer virtual walls or on-line lying in state, as it feels that a place where a loved one is being waked should not become a Facebook page. To sum up, this goes to show that social habits with regard to wakes have changed and that there is room in the market for technologies that at present are complements to traditional undertaker's services.

In a context where very many deaths are occurring, all this not only permits the spreading of concepts of death, traditions and rituals, but also increases their visibility and popularizes them. Moreover, it encourages new forms of mourning, allowing emotions to be expressed on a profile created by, and belonging to, the person now deceased rather than setting up new representations of this personality. Work such as that done by Roberts (2004) suggests that these practices have a particularly positive effect on those afflicted, because they help them to avoid delay in the normal grieving process and alleviate individual suffering.

For the moment, with data traffic on the Internet at the highest levels ever recorded, technology has saved human relationships. Families and friends can stay in touch through video calls. While technology can never replace a kiss or a hug, as it cannot substitute for people, at least for the present it makes it possible to remain close.

\section{Coda}

This health crisis has seen increased demonstrations of support among people when there is a need for collaboration, say, or for donating or making facemasks. There has been a boom in solidarity, but also in frustration. This angst was expressed by 
Doctor Jesús Sánchez, responsible for palliative care at the Cruces University Hospital in Bilbao:

I know it's not easy to run epidemiological and humanitarian measures in tandem. But, in my opinion, for epidemiological reasons we've been neglecting humanitarian questions. We're all going to die one day. From cancer, an accident, plain old age, or from Covid-19. And whatever the cause might be, we shouldn't let anyone die on their own, whether it's in their own home or in hospital.

In this post-industrial world run on the lines of neoliberal capitalism, it is difficult to uncouple the health crisis from economic crisis. In fact, Caritas, the Roman Catholic Church's official confederation of bodies for charitable and social works, has put out a slogan saying that the damage should be counted in terms of thousands of victims, not of millions of euro lost in the economy. Moreover, some countries like the United Kingdom, the United States or Sweden had culturally different ways of confronting the risks (García Acosta 2005) and the moral implications with which risks are always laden (Douglas 1996). Their decision-making and adoption of health measures seemed to aim at protecting the economy more than the public health of their citizens, even if later there were rectifications. In every country there is debate about who should take decisions about the health crisis caused by a pandemic, epidemiologists or economists. Likewise, it has also been recalled during this pandemic that the European Union devastated Southern Europe with its austerity in the 2008 crisis, and today it is gathering up the corpses of those killed by that austerity. The worst harmed, the victims of this pandemic, have been the elderly, whose pensions were often the only help available to many families in trouble in that previous financial and economic crisis. That being said, it was still the case that national budgets continued to be spent on preparations for war, when what finally attacked was a virus. Future studies will have to determine why more investments were not made, worse still there were cutbacks in investment, in science and technology, which alone can promote knowledge and protection of people.

\section{Conclusions}

This investigation has attempted to analyse processes of death and the resolution of grieving brought by the coronavirus pandemic. It has presented general elements corresponding to grief and other more specific items affected by lockdowns, quarantine or the new communication technologies that dominate present-day society.

It has shown how in arrangements for mourning in the time of coronavirus, in bidding farewell, there are no kisses or hugs, and no wakes or viewings to sustain a family, nor a proper funeral. All of this has been suspended. At an interment, there can be just three people present, who must maintain safe distances, and matters must be over in half an hour at most. Hearses enter the grounds and come to a halt, a worker opens the hatch and a priest mutters a few words over a coffin, lacking any floral tributes, which remains in the vehicle. Just a few minutes of responses to give the deceased a final blessing. Everything is very cold, gloomy and hasty, because the 
next hearse is already waiting its turn. To the thousands of dead from coronavirus, with their thousands of different tragedies, must be added those dying from other causes. Because of the situation, they too have been deprived of the farewell they deserved.

The image of a rainbow accompanied by the slogan Todo va a salir bien or Todo saldrá bien [roughly "It will all come right in the end"] has become fashionable in Spain. It is an indication of a time when there is hope, but for the moment there is no sign of the sun, even if there is a rainbow. While everybody is praying for it, nobody knows exactly when everything will come right once again.

Grieving has become another dimension to be re-invented in the present social context. The watchword for the moment must be to protect the health of society. However, in doing so, care must be taken that social distancing does not equate to emotional distancing, nor physical isolation to isolation in life, if there is to be any hope that family members can manage to find closure for their sorrow in the face of these thousands of dead who have not been waked or viewed.

Funding Funding information is not applicable/No funding was received.

\section{Compliance with Ethical Standards}

Conflict of interest The authors declare that they have no conflict of interest.

Ethical Approval All procedures performed in studies involving human participants were in accordance with the ethical standards of the institutional and/or national research committee and with the 1964 Declaration of Helsinki and its later amendments or comparable ethical standards.

Human and Animal Rights This article does not contain any studies with animals performed by any of the authors.

\section{References}

Ariès, P. (1982). Historia de la muerte en Occidente; desde la Edad Media hasta nuestros días. Barcelona: El acantilado.

Attig, T. (2002). The heart of grief: death and the search for lasting love. New York: Oxford University Press.

Bourdieu, P., \& Thompson, J. (1991). Language and symbolic power. Cambridge: Harvard University Press.

Bowlby, J. (1980). La pérdida afectiva: Tristeza y depresión. Barcelona: Paidós.

Davidson, A. D. (1979). Disaster: Coping with stress. A Program that Worked, 1, 20-22.

Dossey, L. (1993). Healing words. The power of prayer and the practice of medicine. San Francisco: Harper Edit.

Douglas, M. (1996). La aceptabilidad del riesgo según las ciencias sociales. Barcelona: Paidós.

Ekman, P. (2003). Darwin, deception, and facial expression. Annals of the New York Academy of Sciences, $1000(1), 205-221$.

Ferrándiz, F. (2014). El pasado bajo tierra: exhumaciones contemporáneas de la Guerra Civil. Barcelona: Anthropos.

Freud, S. (1914). Duelo y Melancolía (Vols. Obras Completas, 1974). Madrid: Biblioteca Nueva Madrid. Galindo, G. C. (2004). Ethos Vital y Dignidad Humana. Bogota: Pontificia Universidad Javeriana. 
García Acosta, V. (2005). El riesgo como construcción social y la construcción social de riesgos. Desacatos, $19,11-24$.

Greyson, B. (1985). A typology of near-death experiences. American Journal of Psychiatry, 142, 967-969.

Kelly, K. V. (2011). Bereavement, Doubt, and the Loved Body: A 9/11 Meditation. Journal of Religion and Health, 50, 516. https://doi.org/10.1007/s10943-011-9513-5.

Klein, M. (1940). Mourning and its relation to manic-depressive states. The international journal of psycho-analysis.

Kübler-Ross, E. (1994). Sobre la muerte y los moribundos. Barcelona: Grijalbo.

Kübler-Ross, E. (2014). La muerte: Un amanecer. Barcelona: Luciérnaga.

Lindemann, E. (1944). Symptomatology and management of acute grief. American Journal of Psychiatry, 10, 141-149.

Loraux, N. (1990). Les mères en deuil. Paris: Editions du Seuil.

Martin, T., \& Doka, K. (1996). Masculine grief. En Doka, K. (comp.) Living with grief: after sudden loss (pp. 161-171). Washington DC: Taylor and Francis.

Merriam, S. B. (1998). Qualitative research and case study applications in education. Revised and expanded from Case Study Research in Education. New York: Wiley.

Meyer, M. (2003). Entre la teoría, el método y la política: la ubicación de los enfoques relacionados con el ACD. In R. Wodak \& M. Meyer (Eds.), Métodos de análisis crítico del discurso (pp. 35-60). Barcelona: Gedisa.

Moody, R. (1975). Life after live. Atlanta: Mockingbird Books.

Moragas, M. (1995). Mass media e identidad cultural en una época de cambios en la comunicación. Bilbao: Servicio de Estudios BBV.

Niemeyer, R. (2002). Aprender de la pérdida: una guía para afrontar el duelo. Barcelona: Paidós.

Nomen Martín, L. (2007). El duelo y la muerte: el tratamiento de la perdida. Madrid: Pirámide.

Parkes, C. M. (1972). Bereavement: Studies of grief in adult life. New York: International University Press.

Parkes, C. (2000). Conclusions II: Attachment and losses in cross cultural perspective. In C. Parkes, P. Laungani, \& B. Young (Eds.), Death and Bereavement across cultures (pp. 233-243). London: Routledge Editions.

Poch, C., \& Herrero, O. (2003). La muerte y el duelo en el contexto educativo: Reflexiones, testimonios y actividades. Barcelona: Paidós.

Rando, T. (1984). Grief, dying, and death. New York: Research Press Company.

Riessman, C. (2008). Narratives methods for human sciences. Thousand Oaks: Sage.

Roberts, P. (2004). Here Today and Cyberspace Tomorrow: Memorials and Bereavement Support on the Web. Generations, 28, 2, Summer https://www.questia.com/library/journal/1P3-687006931/heretoday-and-cyberspace-tomorrow-memorials-and.

Rook, K. S. (1987). Social support versus companionship: Effects on life stress, loneliness, and evaluations by others. Journal of Personality and Social Psychology, 52(6), 1132-1147.

Rosemblatt, P. (1999). The social context for private feelings. In M. Stroebe, W. Stroebe, \& R. Hansson (Eds.), Handbook of bereavement. Theory, research and intervention (pp. 102-111). London: Cambridge University Press.

Sanders, C. (1999). Risk factors in bereavement outcome. In M. Stroebe, W. Stroebe, \& R. Hansson (Eds.), Handbook of Bereavement. Theory, research and intervention (pp. 255-267). London: Cambridge University Press.

Sanz, J. (1995). Comunicación e información. Medicina clínica, 104, 59-61.

Schieffelin, E. (1985). Performance and the cultural construction of reality. American Ethnologist, 12(4), $707-724$.

Schuchetr, S., \& Zisook, S. (1993). Uncomplicated bereavement. Journal of Clinical Psychiatry, 54, 365-372.

Siegel, J. M., \& Kuykendall, D. H. (1990). Risk factors in bereavement outcome. In M. Stroebe, W. Stroebe, \& R. Hansson (Eds.), Handbook of Bereavement. Theory, research and intervention. London: Cambridge University Press.

Simons, B. G. (1979). A time to grieve. New York: Family Service Association.

Stroebe, M., Stroebe, W., \& Hansson, R. (1999). Contemporary themes and controversies in bereavement research. In Handbook of Bereavement: Theory, Research and Intervention (pp. 457-475). London \& New York: Cambridge University Press. 
Stylianos, S., \& Vachon, M. (1999). The role of social support in bereavement. In M. Stroebe, W. Stroebe, \& R. Hansson (Eds.), Handbook of Bereavement. Theory, research and intervention (pp. 397-410). London: Cambridge University Press.

Thomas, L.-V. (1993). Antropología de la muerte. México: Fondo de Cultura Económica.

van Dijk, T. A. (1999). Critical discourse analysis and conversation analysis. Discourse and Society, $10(4), 459-460$.

van Dijk, T. A. (2000). El estudio del discurso. In T. A. Van Dijk (Ed.), Estudios sobre el discurso. Una aproximación interdisciplinaria (pp. 21-66). Barcelona: Gedisa.

Weiss, R. (1999). Loss and recovery. In M. Stroebe, W. Stroebe, \& R. Hansson (Eds.), Handbook of Bereavement. Theory, research and intervention (pp. 271-284). London: Cambridge University Press.

Weiss, G., \& Wodak, R. (Eds.). (2002). Critical Discourse Analysis. Theory and Interdisciplinarity. Palgrave: Macmillan.

Wodak, R. (2003). De qué trata el análisis crítico del discurso -(ACD)- Resumen de su historia, sus conceptos fundamentales y sus desarrollos. En Wodak, R. \& Young.

Worden, J. (1997). El tratamiento del duelo: Asesoramiento psicológico y terapia. Barcelona: Paidos.

Worden, J. (2009). Grief counseling and grief therapy: A handbook for the mental health practitioner. New York: Springer.

Publisher's Note Springer Nature remains neutral with regard to jurisdictional claims in published maps and institutional affiliations. 